Rok XVI (2021) | 2 (32) | S. 107-118

https://doi.org/10.12797/LV.16.2021.32.10

Marcin Zabawa (1)

Uniwersytet Śląski, Katowice

marcin.zabawa@us.edu.pl

\title{
O COMING OUCIE I WYRAŻENIACH POKREWNYCH W POLSZCZYŹNIE ${ }^{1}$
}

Słowa klucze: zapożyczenia właściwe, anglicyzmy, coming out, outing Keywords: lexical borrowings, anglicisms in Polish, coming out, outing

\section{Wprowadzenie}

Celem niniejszego artykułu jest analiza funkcjonowania anglicyzmu leksykalnego coming out (jak również różnego rodzaju wyrazów pochodnych, takich jak outing, a także kalki frazeologicznej wyjść $z$ szafy < ang. to come out of the closet) $\mathrm{w}$ polszczyźnie ogólnej. Konstrukcje ${ }^{2}$ te są bardzo ciekawe, używane w wielu różnych kontekstach, czasem dość mocno od siebie odległych. Przyjrzymy się zatem ich znaczeniom i użyciu w polszczyźnie. Najpierw jednak krótko prześledzimy rozwój struktury wyjściowej (to come out) w angielszczyźnie.

1 Dziękuję dwóm Recenzentom wcześniejszej wersji niniejszego artykułu za cenne dla mnie uwagi i propozycje poprawek.

2 Określeń konstrukcja oraz wyrażenie używam w artykule w ogólnym, tj. niespecjalistycznym znaczeniu (por. definicje w WSJP PAN). Ze względów stylistycznych będą one używane zamiennie, choć jestem świadom, że to pewne uproszczenie. 


\section{Wyrażenie to come out w angielszczyźnie ${ }^{3}$}

Wyrażenie to come out ma w angielszczyźnie wiele znaczeń (niektóre z nich pojawiały się już w staroangielszczyźnie, por. OED). Nas interesuje jednak to, które pojawiło się w XVIII w.: '(o młodej kobiecie wywodzącej się z wyższych warstw społecznych) oficjalnie pojawić się po raz pierwszy na balu lub podobnej imprezie towarzyskiej'4 (pierwsze poświadczone użycie w 1782 r., OED, zob. też szczegółowy opis w pracy Małgorzaty Kity (2016: 11-32)). Znaczenie to prawdopodobnie wpłynęło, jak twierdzi OED, na późniejsze, a mianowicie 'zdać sobie sprawę, że jest się osobą homoseksualną; poczuć, że jest się częścią środowiska homoseksualnego' (potwierdzone użycie w 1941 r., obecnie klasyfikowane przez słownik jako rzadkie), a później 'zaprzestać ukrywania swojej homoseksualnej orientacji przed innymi' (potwierdzone użycie w 1970 r.). Również konstrukcja rzeczownikowa coming out była początkowo używana w znaczeniu 'faktu zdania sobie sprawy przed sobą samym, że jest się osobą homoseksualną (i ewentualnie odkrycia się przed innymi gejami i lesbijkami)' (potwierdzone użycie w 1949 r., obecnie również klasyfikowane jako rzadkie), a później 'faktu potwierdzenia (publicznego lub na przykład w kręgu znajomych), że jest się osobą homoseksualną' (potwierdzone użycie w 1973 r.).

Równocześnie należy wspomnieć o takich angielskich konstrukcjach, jak a skeleton in the closet oraz a skeleton in the cupboard (dosł. 'szkielet w szafie', 'szkielet w kredensie'), definiowanych przez OED jako 'ukryte źródło wstydu lub bólu u jakiejś osoby lub rodziny'. Ich pierwsze potwierdzone poświadczenia pojawiły się w angielszczyźnie pisanej w 1845 r. (OED), ale - jak stwierdza słownik - struktura ta była w użyciu już wcześniej. Nieco później (pierwsze poświadczenie w 1857 r.) zaczęły pojawiać się konstrukcje czasownikowe typu to bring/drag the skeleton out of the closet ('przynieść/wyciągnąć szkielet z szafy') w znaczeniu 'publicznie ujawnić coś, co było wcześniej utrzymywane w tajemnicy lub w inny sposób ukryte’. W późniejszym okresie, co istotne, szkielet został zastąpiony innymi rzeczownikami, na przy$\mathrm{kład}$ take the subject out of the closet ('wyjać temat z szafy'). W XX w. konstrukcja to come out of the closet (wyraz closet 'szafa' został najpewniej przejęty z omówionej wyżej konstrukcji take (something) out of the closet) zaczęła być używana, początkowo w Stanach Zjednoczonych (OED), na określenie zakończenia zaprzeczania bycia gejem lub lesbijką (początkowo głównie przed sobą samym), a nieco później także zakończenia ukrywania (przed innymi) swojej homoseksualnej orientacji.

Doszło tutaj zatem, jak stwierdza anglojęzyczna Wikipedia, do swego rodzaju zmiany konotacyjnej: o ile pierwotnie wyrażenia to come out / coming out kojarzyły się z „wejściem do świata nadziei”, o tyle później ciężar znaczeniowy przesunął się

3 Niniejsza część artykułu ma charakter wprowadzający i służy jedynie zarysowaniu tła dalszych rozważań; co za tym idzie jest ona z konieczności skrótowa i nie powinna być postrzegana jako szczegółowe studium etymologiczne angielskiego wyrażenia to come out. 
ku „Wyjściu z szafy, tj. czegoś ciemnego i nieprzyjaznego" ${ }^{5}$ (zob. też monografię M. Kity (2016: 10-11, 33-38)).

Jak wskazuje OED, wyrażenie to come out powiększa swój zakres użycia i pojawia się w odniesieniu do innych spraw związanych z płciowością i seksualnością, a także innych zjawisk i sytuacji (już niezwiązanych z preferencjami seksualnymi), które - w określonych środowiskach czy społecznościach - mogą być postrzegane jako wstydliwe lub kłopotliwe, na przykład choroba psychiczna, przynależność do określonej grupy etnicznej czy organizacji itp.

Nie sposób stwierdzić, jak często omawiane wyrażenia występują w języku angielskim w znaczeniach związanych z płciowością i seksualnością. Można oczywiście łatwo sprawdzić, że na przykład w korpusie COCA znajdziemy ponad 111000 wystąpień wyrażenia to come out (i pochodnych), ale nie jest możliwe ustalenie, jak duży odsetek odnosi się ujawnienia swej nieheteroseksualnej orientacji. Dzieje się tak ze względu na fakt, że omawiana struktura jest polisemiczna i może występować w bardzo wielu różnych znaczeniach.

\section{Wyrażenie coming out w polszczyźnie: uwagi wstępne ${ }^{6}$}

Trudno jednoznacznie określić, kiedy po raz pierwszy pojawiło się w polszczyźnie wyrażenie coming out (anglicyzm leksykalny). Pewną wskazówką mogą być tutaj badania korpusowe: w NKJP omawiana konstrukcja pojawiła się po raz pierwszy w 2001 r. (dwa poświadczenia: jedno w czasopiśmie „Polityka”, drugie w grupie dyskusyjnej Usenet). Wydaje się zatem, że można z dużą dozą prawdopodobieństwa stwierdzić, że wyrażenie to pojawiło się w polszczyźnie wiele lat po pojawieniu się nowego znaczenia angielskiego to come out.

Nie jest też łatwo zawyrokować o częstotliwości jego występowania w polszczyźnie. Pojawia się ono często, co oczywiste, w czasopismach czy na forach internetowych skierowanych do społeczności LGBT+; artykuł niniejszy koncentruje się jednak na polszczyźnie ogólnej. Podobnie pewną wskazówką mogą być badania korpusowe: w NKJP mamy 290 poświadczeń konstrukcji coming out ${ }^{7}$ (wliczając w to formy odmienione typu coming outy, coming oucie itp., a także dwa wystąpienia bardziej potocznego wariantu comin' out (korpus pełny, wyszukiwarka Pelcra)) ${ }^{8}$.

5 Zob.: https://en.wikipedia.org/wiki/Coming_out.

6 Artykuł niniejszy skupia się na językoznawczym omówieniu wyrażenia coming out. Omówienie coming outu ze społeczno-kulturowo-literaturoznawczego punktu widzenia można znaleźć w przywoływanej już wyżej monografii Małgorzaty Kity (2016).

7 Spotykany jest zarówno zapis coming out, jak i coming-out, przy czym ten drugi, jak wskazuje NKJP, jest znacznie rzadszy.

8 Trzeba jednak dodać, że znaczna liczba użyć (103) nie dotyczy omawianego znaczenia. W NKJP pojawiają się bowiem części tytułów piosenek czy książek (Fire Coming out of the Monkey’s Head), 
Widać zatem, że liczba wystąpień wyrażenia coming out w NKJP nie jest zbyt wysoka. Korpus zawiera 1524696745 słów, a zatem omawiane wyrażenie - traktowane jako jeden leksem - stanowi około o,oooo2\% korpusu; trzeba jednak pamiętać, że kompilowanie NKJP zakończyło się w roku 2012 i od tego czasu nie jest on rozwijany.

Zupełnie inaczej sytuacja przedstawia się w przypadku korpusu MoncoPL (Pęzik 2020): w korpusie tym znajdziemy 3537 poświadczeń omawianego wyrażenia (wliczając $w$ to formy odmienione), co stanowi już o,oooo5\% całości (MoncoPL to obecnie, w styczniu 2021 r., około 7043000 ooo słów), a więc ponad dwa razy więcej niż w wypadku NKJP9. Wyraźnie widać zatem, że częstość konstrukcji coming out w polszczyźnie ma dzisiaj tendencję wzrostową. Nie jest to jednak niespodzianka, jeśli wziąć pod uwagę fakt, że temat związków osób tej samej płci jest często obecny w debacie publicznej, w wystąpieniach polityków czy różnych dyskusjach w mediach, zwłaszcza mediach społecznościowych.

Zgodnie z zasadą, że zapożyczane są głównie rzeczowniki (zob. Mańczak-Wohlfeld 1995: 54-55; Witalisz 2016: 54-55), co wynika z potrzeb nominatywnych, zapożyczenie to pojawiło się w polszczyźnie w formie rzeczownikowej (coming out), konstrukcje czasownikowe nie są natomiast używane (por. konstrukcję ${ }^{*}$ comingoutować ${ }^{10}$; nie jest także używane wyrażenie to come out $\left.{ }^{11}\right)$; występują za to struktury omowne typu zrobić coming out, dokonać coming outu, być po coming oucie itp.

\section{Użycie wyrażenia coming out w polszczyźnie}

Po nakreśleniu krótkiego tła historycznego możemy przejść do analizy wyrażenia coming out. Zacznijmy od porównania definicji omawianej formy w różnych słownikach języka polskiego. Wyrażenie to zostało uwzględnione w SZA oraz WSJP PAN. Przyjrzyjmy się zatem słownikowym definicjom:

publiczne ujawnienie swojej orientacji seksualnej lub swojego pochodzenia (SZA);

nazwy własne (tytuł wystawy młodych twórców) lub różnego rodzaju cytaty z konstrukcji angielskich (na przykład na forach internetowych).

9 Liczba wystąpień omawianego wyrażenia w MoncoPL jest zbyt duża, aby badać każde z nich, ale pobieżne przejrzenie wyników wyraźnie wskazuje, że w korpusie tym - w odróżnieniu od NKJP rzadsze są użycia będące na przykład tytułami piosenek, innymi nazwami własnymi lub cytatami angielskich zdań (w pierwszych 100 wystąpieniach znalazłem jedynie 13 takich przypadków), co dodatkowo potwierdza tezę o wzroście częstości.

10 Potencjalnego słowa comingoutować nie znalazłem ani w NKJP, ani w MoncoPL. Pojedyncze wystąpienia znajdziemy za pośrednictwem wyszukiwarki Google; jest ich jednak zbyt mało (15 wystąpień w postaci bezokolicznika (styczeń 2020)), aby mówić o ich szerszym użyciu w polszczyźnie.

11 W NKJP oraz MoncoPL konstrukcja to come out pojawia się głównie w cytatach anglojęzycznych, choćby w tekstach piosenek, i nie ma wiele wspólnego ze znaczeniem omawianym w niniejszym artykule. 
ujawnienie własnej nieheteroseksualnej orientacji lub tożsamości płciowej nieuznawanej za normatywną (WSJP PAN).

Dodatkowo WSJP PAN dodaje notkę o użyciu (niebędącą jednak częścią definicji): „Bywa używane także w odniesieniu do aktu ujawniania innych cech lub poglądów, które są uważane za odbiegające od powszechnych w danym społeczeństwie". Widać zatem, że omawiane słowniki bardzo szeroko definiują znaczenie coming outu, nie zawężając go do jedynie orientacji homoseksualnej.

Trzeba jednak podkreślić, że zdecydowana większość wyrażeń znalezionych zarówno w NKJP (około 140 na 187 wystąpieńn $^{12}$, zatem około 75\%), jak i we fragmencie MoncoPL (około 60 na 87 wystąpień $^{13}$, czyli około 69\%) odnosi się do orientacji homoseksualnej, co pozwala przypuszczać, że to znaczenie jest nadal podstawowe i dominujące ${ }^{14}$, por. wybrane przykłady ${ }^{15}$ :

(1) Kinga nie miała kłopotów z domowym coming out ${ }^{16}$ (ujawnienie orientacji) (brak tytułu artykułu, „Polityka” 2004) ${ }^{17}$.

(2) Ostatnio miały miejsce moje pierwsze coming outy przed przyjaciółmi [...] (Jak powiedzieć rodzicom, że jestem gejem?, www.forumowisko.pl 20o8).

(3) Zapytaj znajomych, którzy są już po coming oucie, jak to było [...] (Inny nie znaczy gorszy. Czyli zapomnieć to wszystko, „Gazeta Pomorska” 2009).

Kilka przykładów odnosi się do orientacji biseksualnej, a także transseksualizmu (jest to jednak użycie rzadsze niż dotyczące orientacji homoseksualnej):

(4) Nauka coraz dokładniej przygląda się biseksualistom. [...] W Polsce o nich się nie pisze w prasie [...]. Nie robią głośnych coming outów [...] (Dwuramienni, „Polityka” 2009).

(5) Tutaj dwie transseksualistki robią coming out (wykop.pl 2020).

12 Podaję tutaj przybliżoną liczbę (około 140) ze względu na fakt, że nie zawsze korpus przytacza wystarczająco obszerny kontekst, aby można było z całą pewnością określić znaczenie omawianej konstrukcji. Do całkowitej liczby wystąpień (187) nie zostały wliczone cytaty angielskie, nazwy własne itp. (290-103).

13 W 100 początkowych wystąpieniach 13 to anglojęzyczne cytaty, nazwy własne itp. (por. przypis 9). Pod uwagę wzięto zatem 87 początkowych wystąpień. Podobnie jak w wypadku NKJP (por. przypis 12), podano przybliżoną liczbę.

14 Dane dla NKJP i MoncoPL są zbliżone, jednak wydają się sugerować, że wzrasta częstość dodatkowych użyć (tj. niezwiązanych z orientacją homoseksualną, zob. dalszą część artykułu).

15 Wszystkie przykłady przywołane w artykule pochodzą z NKJP lub MoncoPL.

16 Widać wyraźnie, że dawniej słowo było traktowane jako nieodmienne; w przykładach późniejszych jest już odmieniane.

$17 \mathrm{~W}$ przywoływanych cytatach poprawiono oczywiste usterki o charakterze ortograficznym czy interpunkcyjnym, nie wprowadzono jednak innych zmian. 
Zdarzają się także - aczkolwiek już poza NKJP i MoncoPL - użycia związane $\mathrm{Z}$ aseksualizmem.

Inne przykłady - ponownie zaczerpnięte z NKJP i MoncoPL - odnoszą się między innymi do kobiet będących w ciąży (i niekrępujących się na przykład rozebrać publicznie, odsłaniając brzuch) (przykład (6)), kobiet, które dokonały aborcji (przykład (7)), osób, które dokonały apostazji, czyli formalnego wystąpienia z Kościoła katolickiego (przykład (8)), chorują na chorobę nowotworową lub chorobę psychiczną (przykłady (9)-(10)), przyznają się do palenia marihuany (przykład (11)), zaprzestają ukrywania swojego żydowskiego pochodzenia (przykład (12)), określają się jako osoby przynależące do nieuznanej oficjalnie narodowości (przykład (13)), określają się jako feministki (przykład (14)), ujawniają swoje poglądy polityczno-społeczno-gospodarcze (przykłady (15)-(16)) czy też swoje nietypowe zainteresowania, choćby zamiłowanie do oglądania filmów animowanych kierowanych do dzieci (przykład (17)):

(6) Ciążowy coming out dokonał się nawet w kraju muzułmańskim - w 2009 roku na okładce marokańskiego pisma „Femmes du Maroc” pojawiło się zdjęcie nagiej ciężarnej reporterki Nadii Larguet (gazeta.pl 2010).

(7) Tygodnik pisze też o „modzie na aborcyjny coming out” (tok.fm 2014).

(8) [...] na naszej stronie internetowej zamieściliśmy listę ateistów i agnostyków. W ciągu pół roku wpisało się tam ponad 10 tys. osób. To taki ateistyczny coming out (Wyznanie niewiary, „Polityka” 2008).

(9) Dlaczego tak mało ludzi decyduje się na nowotworowy coming out? (www. tygodnikprzeglad.pl 2020).

(10) Grzegorz, kumpel Arka z psychiatryka, jedyny, jakiego ma, marzy o tym, żeby dostać etat $\mathrm{w}$ zakładzie pracy chronionej, bo tam będzie się mógł wreszcie ujawnić bez konsekwencji. Zrobić swój coming out (Co zamknąć, co otwo$r z y c ́$ ?, „Polityka” 2008).

(11) Celem numer dwa jest „coming out” (ujawnianie się) użytkowników marihuany (mmwarszawa.pl 2012).

(12) Mój coming out jako Żydówki wydarzył się trochę mimochodem [...] (Agnieszka Graff, Rykoszetem. Rzecz o ptci, seksualności i narodzie 2008).

(13) Opolskich Ślązaków coming out (gazeta.pl 2012).

(14) Powiedzieć o sobie feministka to była wtedy łata - wielkie życiowe coming out, ujawnienie, jak u gejów i lesbijek (Rychły zgon patriarchatu, „Polityka” 2005).

(15) Po moim neoliberalnym coming oucie nie ośmieliłbym się skrytykować takiej postawy (spidersweb.pl 2016).

(16) Czy nie przywdział Pan łaszków wolnorynkowca dla kamuflażu i w rzeczywistości zamierza Pan zmarginalizować wolnościowców w koalicji, by potem zrobić coming out jako narodowy etatysta? (wykop.pl 2020). 
(17) Ale wydaje mi się, że serial ogląda naprawdę wielu dorosłych facetów, którzy wstydzą się do tego przyznać. Ale taki kucykowy coming out naprawdę pomaga [...] (emetro.pl 2012).

Inne przykłady znalezione w korpusach NKJP i MoncoPL dotyczą między innymi osób publicznie potwierdzających swoją wiarę w Boga i/lub przynależność do Kościoła katolickiego (religijny coming out), ujawniających swoje zarobki współpracownikom (zarobkowy coming out), kobiet mających za sobą doświadczenie poronienia (poronieniowy coming out), osób mających problemy ze zbyt bujnym (lub przeciwnie - zbyt skąpym) owłosieniem na głowie i/lub ciele (włosowy coming out), dziennikarza mediów katolickich, który przyznał, że nie przeczytał Biblii (biblijny coming out) itp. Wydaje się zatem, że coming out może być dziś użyty w praktycznie dowolnym kontekście związanym z faktem ujawniania komuś jakiejś informacji o sobie - choćby najbardziej trywialnej.

$\mathrm{W}$ tym miejscu w naturalny sposób nasuwa się pytanie, czy takie rozszerzanie znaczenia jest wynikiem wpływu angielszczyzny, czy raczej pojawia się już na gruncie polszczyzny. Trzeba zauważyć, że o ile niektóre z przytoczonych wyżej znaczeń pojawiają się w angielszczyźnie - coming out związany z ateizmem, określoną religią lub problemami ze zdrowiem psychicznym (przykłady takie można odnaleźć w COCA) - o tyle nie natrafiłem na przykłady związane choćby z aborcją. Wydaje się zatem, że chociaż na początku wpływ semantyki angielskiej nie był zapewne bez znaczenia (trudno jednak jednoznacznie rozstrzygnąć, czy odgrywał rolę decydującą), to obecnie omawiane wyrażenie rozwija się już na gruncie polszczyzny, bez pośrednictwa angielskiego (świadczą o tym takie konstrukcje, jak aborcyjny czy włosowy coming out).

Konstrukcja coming out bywa również używana żartobliwie, choćby w odniesieniu do akcji pokazywania swoich fotografii (a także fotografii różnych przedmiotów, takich jak choinki bożonarodzeniowe) na jednej z grup dyskusyjnych (przykłady można znaleźć w korpusie MoncoPL). Warto wreszcie wspomnieć, że wyrażenie coming out pojawia się też w znaczeniu bardziej dosłownym, jako wyjście (z czymś, na przykład ze swoją twórczością) do innych ludzi, a także fizyczne ujawnienie się (o jakimś zjawisku, problemie, o jakiejś chorobie). Są to jednak użycia stosunkowo rzadkie i mogą być określone jako poboczne (podany niżej przykład dotyczy ostatniego znaczenia):

(18) Żartuje, że rak znalazł sobie kiepski moment na „coming out” (Do wesela się zagoi, „Gazeta Krakowska” 2006).

Omawiane wyrażenie występuje w polszczyźnie w różnych postaciach graficznych: poza standardowym zapisem coming out (a także rzadszym coming-out) spotyka się również comming out, kaming aut czy kaming ałt (są one jednak rzadkie: 
comming out ma 67 poświadczeń w MoncoPL i jedno w NKJP, kaming aut jedno w MoncoPL i brak poświadczeń w NKJP, zaś kaming ałt jedno w NKJP i brak w MoncoPL). To sugeruje, że asymilacja omawianej konstrukcji postępuje nie na poziomie graficznym, ale przede wszystkim morfologicznym.

W środowisku osób nieheteroseksualnych wyrażenie coming out jest czasem skracane (w języku pisanym) do $C O^{18}$ (zapisywanego także jako $c$-o); spotyka się również (choć jest to wyraźnie rzadsze) jego skracanie do samego coming. Przykłady takie można znaleźć choćby na forum internetowym przeznaczonym dla osób LGBT+ (Forum Homogenizowane; forumlgbt.pl). Nie będą one jednak szerzej tutaj omawiane ze względu na fakt, że artykuł koncentruje się na polszczyźnie ogólnej.

\section{Inne wyrażenia używane w polszczyźnie}

Oprócz opisanego wyżej wyrażenia coming out używana jest również w polszczyźnie kalka z języka angielskiego wyjść $z$ szafy (< ang. to come out of the closet); jak jednak wskazują kwerendy w NKJP oraz MoncoPL, jest ona znacząco rzadsza niż coming out, co więcej, znaczna część jej wystąpień nie dotyczy stricte seksualności, lecz raczej kłopotliwych sekretów rodzinnych itp. ${ }^{19}$ (zdarzają się także użycia dosłowne). Ogółem w NKJP znajduje się jedynie 19 poświadczeń tego wyrażenia w odniesieniu do orientacji homoseksualnej (wobec 140 poświadczeń konstrukcji coming out $\mathrm{w}$ tym znaczeniu). Podobne proporcje - tym razem w odniesieniu do wszystkich znaczeń - znajdziemy w MoncoPL: 316 wystąpień zwrotu wyjść z szafy (wraz formami odmienionymi) wobec 3537 poświadczeń wyrażenia coming out. Wyrażenie coming out jest częstsze zapewne dlatego, że jest krótsze i - co za tym idzie - łatwiejsze w użyciu (a dodatkowo sprzyja mu być może jego angielskość).

W tym miejscu nie można nie dodać, że wyraz szafa może być użyty metonimicznie na określenie sytuacji udawania ( $w$ wypadku osoby nieheteroseksualnej) orientacji heteroseksualnej, por. przykłady wynotowane z NKJP i MoncoPL (zob. też Kita 2016: 38, 69-71):

(19) [...] metaforyczna „szafa” - otoczenie, przed którym udajesz hetero - w której siedzisz, jak ten przysłowiowy trup rodzinny (Jestem gejem, www.forumowisko.pl 2005).

18 Nie sposób ustalić, z jaką częstotliwością występuje ten skrótowiec w NKJP czy MoncoPL, ze względu na homografię z bardzo częstym słowem co (odpowiednio ponad 3000000 i 12000000 poświadczeń).

19 W znaczeniu 'kłopotliwych sekretów' używane są również takie konstrukcje, jak szkielet w szafie (prawdopodobnie kalka ang. skeleton in the closet / skeleton in the cupboard) oraz trup w szafie. 
(20) Psychiatrzy w szafach, aktywiści na ulicach. Te dylematy były nieobce wielu innym psychiatrom gejom [...] (onet.pl 2015).

Koniecznie trzeba w tym miejscu wspomnieć o innym anglicyzmie leksykalnym powiązanym tematycznie z wyrażeniem coming out, a mianowicie o słowie outing. Wyraz ten jest używany w języku polskim w znaczeniu 'ujawnienia czyjejś nieheteroseksualnej (zwykle homoseksualnej, rzadziej biseksualnej) orientacji wbrew jego wiedzy i/lub woli', szczególnie w odniesieniu do osób pełniących funkcje publiczne (o czym świadczą jego poświadczenia w NKJP i MoncoPL).

Wyraz outing jest wyraźnie rzadszy niż konstrukcja coming out: w NKJP znajdziemy jedynie 32 poświadczenia, z czego znaczna część pochodzi z tego samego źródła, a mianowicie Wikipedii. Również w MoncoPL liczba poświadczeń jest niewielka (82 wyniki). Co jednak najciekawsze, najstarsze wystąpienie tego słowa w NKJP pochodzi z „Gazety Wyborczej” z 1993 r., a zatem jest znacznie wcześniejsze niż użycie coming outu ${ }^{20}$ :

(21) Stosował pan outing - dwa lata temu w pierwszym programie niemieckiej telewizji (ARD) ujawnił Pan nazwiska homoseksualistów ze świata kultury i polityki. Oczywiście bez ich zgody (Podnieście ręce?, „Gazeta Wyborcza” 1993).

Tak wczesne wystąpienie omawianego leksemu jest zaskakujące także z tego powodu, że - jak się wydaje - wyraz zaczął być używany w polszczyźnie krótko po pojawieniu się takiego znaczenia w języku angielskim (według OED pierwsze poświadczone wystąpienie słowa outing w omawianym znaczeniu pochodzi z 1990 r.). Na marginesie warto dodać, że outing w angielszczyźnie jest dodatkowo definiowany bardziej ogólnie jako ujawnienie jakiejś informacji o kimś bez jego zgody. Także to użycie słownik datuje na podobny okres (1991 r.; OED). To drugie znaczenie, niedotyczące już mniejszości seksualnych, zostało przejęte przez polszczyznę, jednak w dość ograniczonym zakresie ( 5 poświadczeń w tym znaczeniu w MoncoPL, brak takiego użycia w NKJP), por. następujący przykład:

(22) [...] upublicznianie prywatnych materiałów, np. listów lub zdjęć ofiary (outing) (samorzad.pap.pl 2014).

Co bardzo ciekawe, słowo outing jest czasem mylone z wyrażeniem coming out i używane w znaczeniu 'ujawnienia własnej (a nie czyjejś) nieheteroseksualnej orien-

20 Słowo outing nie trafiło jednak (przynajmniej na razie) do słowników języka polskiego, także tych najnowszych (WSJP PAN). 
tacji' (i tym samym odbiega od znaczenia słowa outing w angielszczyźnie, a zatem jest pseudoanglicyzmem semantycznym ${ }^{21}$ ), por. następujące przykłady:

(23) Pisałeś też o outingu. W moim przypadku mama czegoś się wcześniej domyślała, choć raczej [nie] tego, że jestem geyem ${ }^{22}$ (Usenet, pl.sci.psychologia 1999).

(24) W języku angielskim pojawiło się słowo outing oznaczające otwarte przyznanie się do homoseksualizmu (G. Brzozowicz, F. Łobodziński, Sto płyt, które wstrząsnęły światem. Kronika czasów popkultury 2000).

Warto również odnotować istnienie konstrukcji czasownikowej outować się 'dokonywać coming outu' lub outować kogoś (a także wyoutować) 'ujawniać czyjąś nieheteroseksualną orientację', jak również przymiotnika wyoutowany 'ujawniony, jawny'. Co więcej, istnieje w polszczyźnie także forma autować się / autować kogoś (odnotowana już w WSJP PAN ${ }^{23}$, zob. też poświęcony tym formom artykuł Anny Niepytalskiej-Osieckiej (2016)). Formy te budzą pewne wątpliwości etymologiczne: WSJP PAN traktuje wyrazy outować i autować jako warianty o tej samej etymologii, tj. pochodzącej z ang. out. Być może jednak zasadniejsze byłoby klasyfikowanie leksemu autować (w znaczeniu związanym z orientacją seksualną) jako anglicyzmu semantycznego (znaczenia związane na przykład ze sportem pojawiły się niewątpliwie wcześniej niż te związane z orientacją homoseksualną, co potwierdza kwerenda w NKJP), a outować - jako anglicyzmu leksykalnego.

\section{Uwagi końcowe}

Wyrażenie coming out, które początkowo było używane przez środowisko osób LGBT+, pojawia się obecnie coraz częściej w polszczyźnie ogólnej. Dotyczy nie tylko - jak na początku - orientacji homoseksualnej, ale też wszelkich preferencji odbiegających od modelu heteroseksualnego (biseksualizm, aseksualizm itp.). Używane jest także przez osoby heteroseksualne, aby podkreślić pewną nietypowość (na przykład sapioseksualizm).

Co istotniejsze, wyrażenie coming out stale rozszerza swój zakres użycia: dzisiaj, jak się wydaje, może pojawić się w niemal dowolnym kontekście dotyczącym jakiejś

21 Więcej informacji na temat pseudoanglicyzmów i ich typów można znaleźć w monografii Alicji Witalisz (2016: 155-159).

22 Warto zwrócić uwagę na nietypowy zapis tego słowa, będący czymś pośrednim pomiędzy ortografią angielską (gay) i polską (gej). Jak się wydaje, taki zapis był czasem stosowany dawniej, dziś natomiast jest bardzo rzadki (co potwierdza NKJP).

23 Outować również jest odnotowany jako rzadszy wariant leksemu autować, ale tylko w niektórych znaczeniach tego ostatniego. Znaczenie wyrazu autować jest zatem szersze niż znaczenie słowa outować, co potwierdza kwerenda w MoncoPL. 
informacji, którą ktoś do tej pory o sobie ukrywał, a teraz postanowił ją ujawnić (może ona dotyczyć pochodzenia, przynależności do określonej religii lub jej braku, a nawet tak stosunkowo przyziemnych spraw, jak wysokość zarobków czy problemy $\mathrm{z}$ włosami). Co jednak ciekawe, podobnemu rozszerzeniu nie uległo znaczenie wyrazu outing.

Omawiane wyrażenie zostało już zaadaptowane morfologicznie, na co wskazują między innymi obecność liczby mnogiej (coming outy) oraz liczne formy odmienione, zarówno w liczbie pojedynczej, jak i mnogiej (coming outu, coming oucie, coming outem, coming outów, coming outom, coming outach itp.). Zdarzają się także mniej typowe przykłady form odmienionych, na przykład zapisywane $\mathrm{z}$ apostrofem: Im więcej osób dokona coming out'u, tym większa będzie to podpora dla pozostatych, że nie są sami („Gazeta Pomorska” 2009), ale nie są one częste.

Podobnie zaadaptowane są już formy wyoutować oraz outing (por. outingu, outingiem czy outingi). Leksem ten (tj. outing) może jednak sprawiać problemy interpretacyjne i nie zawsze jest rozumiany w taki sam sposób.

Na zakończenie warto pokusić się o krótki komentarz normatywny. W wypadku takich wyrażeń, jak coming out, wyraźnie odczuwana jest ich obcość, zwłaszcza na poziomie grafii. Określenie to jest jednak wygodne w użyciu (może być skracane do $C O$ ), a także bardzo uniwersalne i często stosowane. Jego znaczenie nie rodzi trudności interpretacyjnych; wydaje się zatem, że sformułowanie to może zostać zaaprobowane, choćby ze względu na kryterium uzualne ${ }^{24}$.

Więcej problemów sprawiają takie wyrazy, jak outing. Jakkolwiek pożyczka ta jest przyswojona morfologicznie, to jednak sprawia spore problemy interpretacyjne (por. przykłady przywołane w artykule) i jej znaczenie nie do końca jest jasne. Określenie outing jest też stosunkowo rzadkie i z tych powodów jego zaaprobowanie wydaje się bardziej problematyczne. Również takie leksemy, jak outować się czy wyoutowany wydają się nie do końca uzasadnione: jestem ujawnionym gejem brzmi chyba lepiej niż jestem wyoutowanym gejem.

\section{Literatura}

COCA: Corpus of Contemporary American English, [on-line:] www.english-corpora.org/ coca (dostęp: 15 VI 2020).

Dunaj B., Mrcawka M., 2017, O potrzebnych i niepotrzebnych zapożyczeniach z języka angielskiego, „Annales Universitatis Paedagogicae Cracoviensis” 12, s. 67-80.

KITA M., 2016, Coming out w polskiej przestrzeni dyskursywnej, Katowice.

MAŃCZAK-WoHlfEld E., 1995, Tendencje rozwojowe wspótczesnych zapożyczeń angielskich w języku polskim, Kraków.

24 Więcej informacji o kryteriach oceny anglicyzmów w polszczyźnie można znaleźć w artykule Bogusława Dunaja i Mirosławy Mycawki (2017). 
MoncoPL: Wyszukiwarka korpusowa Monco, [on-line:] monco.frazeo.pl (dostęp: 20 VIII 2021).

Narodowy Korpus Języka Polskiego, praca zbiorowa, red. A. Przepiórkowski, M. Bańko, R.L. Górski, B. Lewandowska-Tomaszczyk, Warszawa 2012.

Niepytalska-Osiecka A., 2016, O najnowszych znaczeniach czasowników wyautować $i$ wyautować się, „Poradnik Językowy” nr 6, s. 77-84.

NKJP: Narodowy Korpus Języka Polskiego, [on-line:] nkjp.pl.

OED: Oxford English Dictionary, [on-line:] oed.com (dostęp: 15 VI 2020).

PęZik P., 2020, Budowa i zastosowania korpusu monitorującego MoncoPL, „Forum Lingwistyczne" 7, s. 133-150, doi.org/10.31261/FL.2020.07.11.

SZA: E. Mańczak-Wohlfeld, L. Wiśniakowska (red.), Słownik zapożyczeń angielskich w polszczyźnie, Warszawa 2010.

Wielki słownik języka polskiego PAN. Geneza, koncepcja, zasady opracowania, praca zbiorowa, red. P. Żmigrodzki, M. Bańko, B. Batko-Tokarz, J. Bobrowski, A. Czelakowska, M. Grochowski, R. Przybylska, J. Waniakowa, K. Węgrzynek, Kraków 2018.

Witalisz A., 2016, Przewodnik po anglicyzmach w języku polskim, Kraków.

WSJP PAN: P. Żmigrodzki (red.), Wielki słownik języka polskiego PAN, [on-line:] www. wsjp.pl.

\section{On coming out and Related Constructions in Polish Abstract}

The aim of the present paper is to discuss the English lexical borrowing coming out, together with some related constructions, used in Polish. The construction in question was originally used in Polish in LGBT community to denote the process of disclosing one's own non-heterosexual orientation; now, however, it has significantly expanded its range of contexts. The construction is thus used in many different contexts, connected with e.g. one's religion, details about one's earnings, etc. Interestingly enough, the meaning of other constructions, such as outing, has not been extended. In the article, descriptions of the meanings of the forms in question have been illustrated with numerous examples taken from the National Corpus of Polish (NKJP) and the MoncoPL Corpus. 